\title{
Itamar Even-Zohar
}

\section{Teoria polisystemów*}

\section{System i polisystem w nowoczesnym funkcjonalizmie: statyka - dynamika}

Założenie, że zjawiska semiotyczne, czyli wzory komunikacji międzyludzkiej rządzone przez znaki (takie, jak: kultura, język, literatura, społeczeństwo) można zrozumieć i zbadać w sposób bardziej adekwatny, postrzegając je jako systemy, nie zaś konglomerat całkowicie różnych elementów, stało się jednym $\mathrm{z}$ wiodących poglądów w większości współczesnych nauk humanistycznych. W miejsce pozytywistycznego gromadzenia danych, zbieranych bona fide na gruncie empirii i analizowanych na podstawie ich materialnej substancji, pojawiło się podejście funkcjonalistyczne, oparte na badaniu relacji. Założenie, że stanowią one systemy, otworzyło drogę hipotezom o tym, w jaki sposób działają różne układy semiotyczne, a w konsekwencji umożliwiło osiągnięcie celu, który w miarę rozwoju nowoczesnej nauki uznano za nadrzędny. Polegał on na wykryciu praw rządzących różnorodnością i złożonością zjawisk, nie zaś na samej ich rejestracji i klasyfikacji. Ponieważ w ujęciach prefunkcjonalistycznych rzadko kiedy dążono do uchwycenia takich zasad, obiekty badań i obserwacji brane wcześniej za "zjawiska” właściwie nie pokrywały się ze „zjawiskami”, na podstawie których można by stawiać hipotezy w ramach podejścia funkcjonalistycznego. Pojęcie systemu umożliwiło zatem nie tylko adekwatne wyjaśnienie faktów „znanych", lecz także odkrycie tych całkowicie „nowych”. Poza tym obiekty znane, dla których dawniej nigdy nie dopuszczano możliwości korelacji z informacjami z reguły związanymi z pewnym "faktem”, teraz stały się dla tego "faktu” znaczące. Funkcjonalizm do głębi zmienił zarówno struktury, jak i metody, zarówno pytania, jak i odpowiedzi - w każdej dyscyplinie, w której go wprowadzono.

- Podstawa przekładu: Itamar Even-Zohar, Polysystem Studies [= „Poetics Today" 11:1, 1990], Durham: Duke University Press, s. 9-27. Całość dostępna pod adresem internetowym: http://www.tau.ac.il/-itamarez/works/books/ez-pss1990.pdf

Przełożony szkic jest częścią wstępu teoretycznego do książki Polysystem Studies. Wszystkie zarysowane tu problemy zostały szerzej omówione w dalszej części pracy oraz zilustrowane przykładami $\mathrm{z}$ literatury rosyjskiej, hebrajskiej $\mathrm{i} w$ języku jidysz. Teorię polisystemów Even-Zohar rozwija systematycznie od lat 70. (Polysystem Theory, „Poetics Today" 1:1-2, 1979, s. 287-310, ostatnia wersja w druku: Polysystem Theory (Revised), w: I. Even-Zohar, Papers in Culture Research 2005, s. 38-49 - dostępna pod adresem internetowym: http://www.tau.ac.il/-itamarez/works/books/EZ-CR-2005.pdf). 
Tym niemniej, mimo powszechnych przesłanek podejście funkcjonalne nigdy nie zostało całkowicie ujednolicone. Mówiąc w skrócie, do obiegu weszły dwa różne i nieprzystawalne do siebie programy. Niestety ten stan rzeczy, nie zawsze właściwie uświadamiany, w znacznym stopniu zaszkodził rozwojowi różnych dyscyplin semiotyki. Niezdolność rozróżnienia między wspomnianymi programami nie tylko doprowadziła do rozpowszechnienia błędnego pojęcia o ich zawartości, ale też utrudniła ocenę, czego mógł dokonać każdy z nich zgodnie ze swym zasadniczym przeznaczeniem. Godne ubolewania, że w niektórych dziedzinach nowoczesnej tradycji semiotycznej fakt ten uznaje się za truizm, podczas gdy obraz sytuacji przedstawiany niewłaściwie - nawet przez profesjonalistów - jest wciąż na porządku dziennym.

W dalszej części niniejszego artykułu wymienione programy określane są jako „teoria systemów statycznych" i "teoria systemów dynamicznych". Tę pierwszą błędnie utożsamia się z podejściem wyłącznie „funkcjonalnym” czy też „strukturalnym”, wspominając o niej zazwyczaj w kontekście nauk de Saussure'a. W pismach szwajcarskiego uczonego i w pracach kontynuujących jego tradycję system oznacza statyczną („synchroniczną”) sieć powiązań, w której wartość każdego elementu jest funkcją jego specyficznych relacji. W ten sposób można wykryć funkcje poszczególnych jednostek, podobnie jak rządzące nimi reguły, natomiast w zasadzie nie istnieje możliwość wyjaśnienia zmian i wariacji. Czynnik następstwa w czasie („diachronii”) zostaje więc wykluczony $\mathrm{z}$ „systemu” i uznany za moment wykraczający poza zasięg hipotez funkcjonalnych. Przyjęto, że diachronia ma charakter pozasystemowy, zaś utożsamienie jej wyłącznie $z$ aspektem historycznym systemu praktycznie eliminuje ją $\mathrm{z}$ dziedziny językoznawstwa.

Korzyści z wprowadzenia pojęcia systemu zamiast mechanistycznego zbioru danych są ewidentne. Nawet redukcja systemu do czynnika niejako ahistorycznego, pozaczasowego, nie jest jako taka stanowiskiem, którego nie dałoby się obronić. Językoznawstwo czasów de Saussure’a, skoncentrowane na zmianach historycznych, pojmowane w kategoriach łagodnie mówiąc - niesystemowych, stanowiło oczywistą przeszkodę w odkryciu mechanizmów funkcjonowania języka - nie zaś tego, jakim przemianom podlega on w kolejnych epokach. Drogą redukcji udało się osiągnąć adekwatny poziom abstrakcji i tym samym odsłonić zasadnicze prawa rządzące działaniem języka. Naturalnie z punktu widzenia tak abstrakcyjnego modelu niekoniecznie trzeba brać pod uwagę możliwość, że $w$ danym momencie $w$ systemie istnieją jednocześnie różne opcje, skoro zasadniczo dają się one zredukować. Jak wiadomo $\mathrm{z}$ innych dziedzin badawczych (np. termodynamiki), z perspektywy metodologicznej bardziej efektywne jest uznanie teorii systemów zamkniętych jako punktu wyjścia. 
W takim rozumieniu podejście statyczne faktycznie spełnia przeznaczoną mu rolę. Jeśli jednak przyjąć je za to, czym nie jest, a mianowicie za model dążący do bliższego wyjaśnienia warunków funkcjonowania systemu w czasie, może ono przeszkodzić $\mathrm{w}$ dociekaniach naukowych. Istnieje oczywista różnica między próbą ukazania głównych zasad rządzących systemem poza czasem, a ujęciem stawiającym sobie za cel wyjaśnienie, w jaki sposób system funkcjonuje zarówno „z zasady”, jak i „w czasie”. Dopuszczając aspekt historyczny jako element stanowiska funkcjonalnego, trzeba uwzględnić kilka konsekwencji. Po pierwsze wypada się zgodzić, że zarówno synchronia, jak i diachronia są historyczne, jednakże wyłączne utożsamianie tej ostatniej $\mathrm{z}$ historią jest nie do przyjęcia. W rezultacie synchronii nie można i nie powinno się zrównywać ze statyką, skoro w dowolnym momencie na osi synchronicznej działa więcej niż jeden układ diachroniczny. Po drugie, jeśli idea ustrukturyzowania i systemowości nie musi już być identyfikowana $\mathrm{z}$ homogenicznością, system semiotyczny można sobie wyobrazić jako strukturę heterogeniczną i otwartą. Dlatego system bardzo rzadko ma charakter "unisystemu"; siłą rzeczy stanowi on "polisystem" - system wielokrotnie złożony, układ rozmaitych systemów przecinających się i częściowo nakładających na siebie, wykorzystujących jednocześnie różne opcje, a przy tym funkcjonujących jako jedna całość o określonej strukturze, której elementy są od siebie współzależne.

Podejście statyczne, synchronistyczne ${ }^{1}$ wywodzi się ze szkoły genewskiej, natomiast ujęcie dynamiczne ma swoje korzenie w pracach rosyjskich formalistów oraz czeskich strukturalistów. Niestety, pochodzące z tego źródła wyobrażenie dynamiki systemu w znacznym stopniu zignorowano zarówno w językoznawstwie, jak i w teorii literatury. Zwycięstwo odniósł (błędnie interpretowany) synchronistyczny punkt widzenia. Zarówno dla laika, jak i dla profesjonalisty „strukturalizm” na ogół wciąż jeszcze równoznaczny jest ze statyką $\mathrm{i}$ synchronizmem, $\mathrm{z}$ jednorodną strukturą i perspektywą ahistoryczną.

\section{Polisystem: procesy i procedury}

\subsection{Ogólne właściwości polisystemu}

W tym kontekście pojęcie „polisystem" jest czymś więcej niż tylko pewną konwencją terminologiczną. Jego wprowadzenie ma na celu sformułowanie koncepcji systemu jako tworu dynamicznego i heterogenicz-

1 Okreslenie „synchronistyczny” wydaje się bardziej adekwatne niż „synchroniczny”, jeśli przyjmiemy, że „synchroniczny” nie musi być równoznaczny z pojęciem „statyczny”. 
nego - w przeciwieństwie do perspektywy synchronistycznej ${ }^{2}$. Proponowany termin podkreśla wielokrotność przecięć i nakładających się na siebie struktur, a zatem wyższy stopień ich złożoności, kładąc przy tym nacisk na fakt, iż jednorodność nie jest niezbędnym warunkiem funkcjonowania systemu. Uznanie historycznej natury systemu (co jest dużą zaletą z punktu widzenia konstruowanych modeli bliższych „światu rzeczywistemu") zapobiega przekształcaniu zjawisk historycznych w serie ahistorycznych, nie powiązanych ze sobą wydarzeń.

Ponieważ operowanie kategorią systemu otwartego jest trudniejsze niż zajmowanie się systemem zamkniętym, wypada przyznać, iż możliwości wyczerpującej analizy mogą się przy tym okazać bardziej ograniczone. Zapewne pozostanie tu więcej miejsca dla „nieprawidłowości”, zaś systemowość nie będzie już błędnie utożsamiana z systematycznością. Oczywiście ma to swoje „wady”, jednak tylko z punktu widzenia teorii systemów statycznych, nie zaś dynamicznych. W rzeczy samej, synchronizm pomaga zrozumieć ogólne pojęcie funkcji i działania, ale nie jest w stanie wyjaśnić, w jaki sposób język - czy też każdy inny system semiotyczny - funkcjonuje na określonym obszarze $w$ czasie. Rozmaitość kulturową społeczeństwa można, rzecz jasna, sprowadzić wyłącznie do kultury klas rządzących, ale takie stanowisko okaże się bezpodstawne, jeśli weźmiemy pod uwagę czynnik czasowy, tzn. możliwość zmiany oraz sterujące nią mechanizmy. Ewidentna różnorodność w kulturze jest szczególnie „namacalna” w przypadkach, gdy dana społeczność jest dwulub wielojęzyczna (stan jeszcze do niedawna powszechny w większości społeczeństw europejskich). Przykładowo, w dziedzinie literatury heterogeniczność objawia się w sytuacji, gdy dana wspólnota posiada dwa systemy literackie (lub więcej) - niejako dwie literatury. Dla literaturoznawców ograniczenie się tylko do jednej z nich i zignorowanie drugiej jest oczywiście znacznie bardziej dogodne niż badanie obydwu. W studiach nad literaturą jest to powszechna praktyka, mimo iż jej rezultaty są wyjątkowo nieadekwatne.

2 Należy jednak koniecznie podkreślić, iż nie istnieje żadna właściwość możliwa do przypisania „polisystemowi”, której nie można by było - jako takiej - przyporządkować „systemowi”. Jeżeli pod pojęciem „systemu” gotowi jesteśmy rozumieć zarówno zamknięty układ relacji, którego elementy nabierają wartości na gruncie opozycji wobec swoich przeciwieństw, jak też $\mathrm{i}$ otwartą strukturę składającą się $\mathrm{z}$ kilku jednoczesnych sieci relacji tego typu, wówczas określenie „system” jest odpowiednie i w zupełności adekwatne. Problem polega na tym, że ugruntowane terminy mają tendencję do "konserwowania" starszych ujęć badawczych. Dlatego konieczne jest stworzenie nowych terminów po to, aby pojęcia, które się za nimi kryją, stały się bardziej wyraziste - nawet jeśli dotychczasowe określenia w zasadzie by wystarczyły. 
Tymczasem hipoteza polisystemów została stworzona po to, by zająć się właśnie takimi - podobnie zresztą jak i mniej ewidentnymi - przypadkami. Umożliwia ona nie tylko uwzględnienie $w$ badaniach semiotycznych takich obiektów (zjawisk, właściwości), które uprzednio przeoczono czy też odrzucono bez ogródek, ale też sprawia, że ich zintegrowanie staje się warunkiem sine qua non dla adekwatnego rozumienia wszystkich dziedzin semiotyki. Oznacza to, że języka standardowego nie sposób rozpatrywać $w$ oderwaniu od szerszego kontekstu, jakim są jego warianty niestandardowe; literatury dziecięcej nie da się analizować jako zjawiska sui generis, ale związanego z literaturą dla dorosłych; przekładów literackich na dany język nie można oddzielić od literatury oryginalnej pisanej w tym języku; literatury masowej (thrillerów, romansów itp.) nie powinno się wykluczać jako „nie-literatury” po to, by uniknąć konstatacji, że jest ona współzależna od literatury „indywidualnej”.

Stwierdzenie, że hipoteza polisystemów zakłada odrzucenie sądów wartościujących jako apriorycznego kryterium doboru obiektów badań, może się wydać trywialne, tym niemniej zasługuje na szczególne podkreślenie - zwłaszcza $\mathrm{w}$ odniesieniu do studiów literaturoznawczych, gdzie wciąż jeszcze krytycyzm bywa mylony $z$ badaniami. Przyjmując hipotezę polisystemów, trzeba jednocześnie zaakceptować fakt, że ukierunkowane historycznie studia nad polisystemami literackimi nie mogą się ograniczać do tak zwanych arcydzieł, nawet jeśli to właśnie one uznawane są przez niektórych za jedyną rację bytu dla badań literaturoznawczych. Elitaryzm tego rodzaju nie da się pogodzić z historiografią literatury, podobnie jak historii powszechnej nie można sprowadzać do biografii królów i generałów. Innymi słowy, naukowcy zajmujący się odkrywaniem mechanizmów rządzących literaturą zapewne nie unikną przyznania, iż wszelkie sądy wartościujące rozpowszechnione $\mathrm{w}$ danym okresie same w sobie stanowią integralną część tych mechanizmów. Żadna dziedzina badawcza, mniej lub bardziej ściśle „naukowa”, nie może dokonywać selekcji swych obiektów zgodnie $\mathrm{z}$ normami panującego gustu.

Rezygnacja $\mathrm{z}$ badań przedmiotów dobranych według gustu nie oznacza tego, że poszczególne „wartości” czy też ewaluacja w ogóle ulegają wykluczeniu przez jakąkolwiek dziedzinę nauk humanistycznych jako aktywne czynniki wymagające wyjaśnienia. Bez analizy takich norm aksjologicznych nie można zrozumieć działania żadnego systemu stworzonego przez człowieka. Pragnę zatem przestrzec przed błędną interpretacją moich argumentów, które nie stanowią apologii żadnego programu „obiektywistycznego" w naiwnym znaczeniu tego słowa. Jak wykażą poniższe rozważania, studia nad normami kulturowymi należą do istoty każdej funkcjonalnej teorii stratyfikacji. 


\subsection{Dynamiczna stratyfikacja i produkty systemowe}

Heterogeniczność można połączyć $\mathrm{z}$ funkcjonalnością pod warunkiem założenia, iż jednostki (elementy lub funkcje), które pozornie nie dają się ze sobą pogodzić, nie tyle pozostają we wzajemnym stosunku jako poszczególne jednostki (elementy lub funkcje), ile raczej stanowią po części alternatywne systemy jednoczesnych opcji.

Systemy te nie są sobie równe, lecz tworzą pewną hierarchię w obrębie polisystemu. Jak sugerował Tynianow, permanentna walka między rozmaitymi warstwami decyduje o tym, że system znajduje się w stanie synchronicznym (dynamicznym). Zmiana na osi diachronii spowodowana jest zwycięstwem jednej warstwy nad drugą. Wskutek tego ruchu odśrodkowego względnie dośrodkowego pewne zjawiska przesuwają się $\mathrm{z}$ centrum na peryferie, podczas gdy inne mogą przenikać do centrum, dążąc do tego, by całkowicie je opanować. Tym niemniej, w odniesieniu do polisystemu nie można mówić o jednym centrum i jednym obszarze peryferyjnym, ponieważ hipoteza zakłada istnienie kilku takich pozycji. Ruch może mieć miejsce np. wtedy, gdy dana jednostka (element lub funkcja) ulegnie przemieszczeniu z peryferii jednego systemu na peryferie sąsiedniego systemu $\mathrm{w}$ obrębie tego samego polisystemu, skąd może (ale nie musi) przesunąc się dalej w kierunku centrum tego drugiego.

W tradycji niejednokrotnie mieliśmy okazję obserwować rezultaty tego typu transferów, przy czym albo nie zdawaliśmy sobie sprawy z tego, że taki ruch się dokonał, albo też ignorowaliśmy jego źródło. Ponieważ w praktyce (uni)system utożsamiano wyłącznie $\mathrm{z}$ warstwą centralną (czyli z kulturą oficjalną przejawiającą się m.in. w języku standardowym, w skanonizowanej literaturze, we wzorcach zachowań preferowanych przez klasy dominujące), peryferie wyobrażano sobie jako obszar pozasystemowy (o ile w ogóle zwracano na nie uwagę). Taki punkt widzenia jest zbieżny $\mathrm{z}$,widokiem wewnętrznym” reprezentowanym przez „ludzi w kulturze"3. Postawa ta doprowadziła do wykształcenia się różnych tendencji. Po pierwsze brak było świadomości napięcia między warstwami w obrębie systemu, dlatego też wartość (funkcja, „znaczenie”) całego szeregu różnorodnych jednostek pozostawała nie wykryta. Te ostatnie znajdowały się w opozycji do innych równoległych jednostek, których istnienie i naturę ignorowano. Po drugie, jak już stwierdzono, proces zmian nie dawał się wytłumaczyć inaczej, jak tylko w kategoriach jednostko-

3 J.M. Łotman, B.A. Uspienski, W.W. Iwanow, W.N. Toporow, A.M. Piatigorski, Theses on the Semiotic Study of Cultures (as Applied to Slavic Texts), w: T.A. Sebeok (red.), The Tell-Tale Sign, Lisse 1975, s. 57-84; C.F. Voegelin, Casual and NonCasual Utterances within Unified Structure, w: T.A. Sebeok (red.), Style in Language, Cambridge 1960, s. 57-59. 
wych innowacji wprowadzanych przez twórcze indywidualności, bądź też poprzez „wpływy” z innych źródeł, przeważnie na poziomie osobniczym, często odizolowanym (inny pisarz, dzieło itd.). Po trzecie, zmiany zaznaczające się w sposób materialny (jako odmienne od samego procesu przeobrażeń) nie poddawały się interpretacji, skoro ich natura była ukryta i niedostępna dla oka obserwatora. Przykładowo, twórczą działalność pisarza zwykło się sprowadzać do mglistych wyobrażeń takich, jak „wyobraźnia” czy „inspiracja”. Posługiwanie się nimi oznacza w istocie rezygnację z możliwości dotarcia do sedna złożonego zespołu zjawisk składających się na warunki, w jakich działa pisarz, a których pewną część stanowią adekwatne ograniczenia, część zaś jest funkcją indywidualnej zdolności autora do stworzenia nowych warunków narzuconych nie je$m u$, lecz przez niego samego.

Dlaczego transfer w ogóle ma miejsce, jakie są jego przyczyny i sposoby aktualizacji (wykonania) w pojedynczych przypadkach - to wszystko pytania, jakie stawia sobie teoria polisystemów, zajmując się poszukiwaniem odpowiedzi z intensywnością wprost proporcjonalną do rosnącej liczby przypadków, w których została poddana próbie na przestrzeni ostatnich lat.

Jedno jest jasne: relacje panujące $\mathrm{w}$ obrębie polisystemu mogą wytłumaczyć nie tylko procesy w nim zachodzące, ale też procedury działające na poziomie repertuaru. Okazuje się bowiem, że ograniczenia płynące $\mathrm{z}$ polisystemu mają znaczenie dla procedur selekcji, manipulacji, amplifikacji, usuwania itd., jakie dokonują się na faktycznych produktach (zarówno werbalnych, jak i niewerbalnych) odnoszących się do polisystemu. Dlatego badacze zainteresowani nie tyle procesami zachodzącymi w ich specyficznej dziedzinie - takiej, jak język czy literatura - ile raczej „właściwym" charakterem jej wytworów (np. wypowiedzi językowych, tekstów literackich) nie mogą nie uwzględniać stanu danego polisystemu, którego produktami się zajmują. Oczywiście, gdyby badać same tylko wytwory oficjalne (wypowiedzi w języku standardowym, ,arcydzieła" literackie), w wielu przypadkach nie można by wykryć, jak funkcjonują ograniczenia polisystemu. Skoro naukowcom nie udało się dostrzec z jednej strony zależności między pozycją tekstów i modeli (właściwości, cech) w obrębie ustrukturyzowanej całości, do której należą, z drugiej zaś strony - decyzji podejmowanych przy ich wytwarzaniu, jedyną możliwością stało się wyjaśnienie indywidualne („błąd”, „niezrozumienie”, „kiepska imitacja" - np. w badaniach nad przekładem) ${ }^{4}$.

4 Autor odsyla tutaj do rozdziału The Position of Translated Literature within the Literary Polysystem (w tej samej pracy, z której pochodzi niniejszy artykuł, s. 45-51), w którym zajmuje się problemem miejsca przekładu w polisystemie literackim (przyp. thum.). 


\subsubsection{Warstwy skanonizowane i nieskanonizowane}

Pierwszym badaczem, który dokonał konceptualizacji socjokulturowych wyróżników produkcji tekstu w kategoriach stratyfikacji literackiej, był zapewne Wiktor Szkłowski. Zgodnie z jego tezami $(1921,1923)^{5}$ pewne właściwości w literaturze stają się kanoniczne, podczas gdy inne nie ulegają kanonizacji. Przy takim ujęciu jako "skanonizowane” rozumiane są normy i utwory literackie (tzn. zarówno modele, jak i teksty), które w dominujących kręgach danej kultury zostały zaakceptowane jako właściwe i których dostrzegalne wytwory są przechowywane przez daną społeczność, stając się częścią jej historycznego dziedzictwa. Z drugiej strony za „nieskanonizowane” uważa się normy i teksty odrzucone przez kręgi opiniotwórcze jako nieadekwatne; na dłuższą metę ich produkty często ulegają zapomnieniu (o ile nie zmienią swego statusu). Kanoniczność nie jest zatem nieodłączną cechą działalności tekstowej na jakimkolwiek poziomie; nie jest ona eufemistycznym określeniem literatury „dobrej” w przeciwieństwie do „złej”. Fakt, że w danym okresie pewne cechy mają tendencję do skupiania się wokół określonego statusu, nie oznacza, że są one "zasadniczo" z nim związane. Oczywiście, w pewnej epoce „ludzie w kulturze” mogą sami dokonywać rozróżnień w takich kategoriach, jednakże historykowi wypada mówić o nich tylko jako o świadectwie istnienia zespołu norm obowiązujących $\mathrm{w}$ danym czasie ${ }^{6}$.

Napięcia między kulturą skanonizowaną a nieskanonizowaną są zjawiskiem uniwersalnym. Dochodzą do głosu w każdej kulturze, ponieważ

5 W późniejszym zbiorze prac O teorii prozy (Moskwa 1925) Szkłowski powtarza niektóre z hipotez postawionych wcześniej w Rozanowie (Petrograd 1921) (zob. zwłaszcza Szkłowski, O teorii prozy, op. cit., s. 226-228). Wkład Szkłowskiego w rozwój teorii badań historycznoliterackich w pełni docenił Borys Eichenbaum (Eichenbaum, Teorija 'formal'nogo metoda', w: tegoż, Literatura, Leningrad 1927, s. 116-148 - przekład polski: Teoria metody formalnej, przel. R. Zimand, w: B. Eichen baum, Szkice o prozie i poezji, wybór i przekład L. Pszczołowska i R. Zimand, Warszawa 1973, s. 285-288).

${ }^{6} \mathrm{~W}$ tym miejscu (podobnie jak w wielu innych) terminologię używaną przez Szkłowskiego trudno uznac za systematyczną. W Rozanowie i innych pracach autor oscyluje między określeniami „literatura nieskanonizowana” a „literatura młodsza” (czy też „linia”: mladszaja literatura [linija]). Ponadto, mimo że w języku rosyjskim słowo "skanonizowany" (kanonizirowannyj) w odniesieniu do kwestii świeckich wydaje się brzmieć bardziej „naturalnie” niż „kanoniczny” (kanoniczeskij), rozróżnienie to zaciera się w niektórych językach - zwłaszcza w angielskim. Podczas gdy pojęcie „kanoniczny" może sugerować (i rzeczywiście sugeruje w pracach wielu krytyków angielsko- czy tė̇ francuskojęzycznych), iż pewne właściwości są $z$ natury „kanoniczne” (franc. canonique), słowo „skanonizowany" (franc. canonisể) jasno podkreśla, że taki stan jest rezultatem pewnego aktu (działania) podjętego $\mathrm{w}$ stosunku do danego materiału, nie zaś pierwotną naturą materiału „samego w sobie". Dlatego uważam za właściwe, aby również w innych językach europejskich postępować zgodnie z praktyką Szkłowskiego. 
nieustratyfikowana społeczność ludzka po prostu nie istnieje - nawet w krainie Utopii. Nie ma takiego języka na ziemi, który nie składałby się $\mathrm{z}$ warstw, nawet jeśli dominująca ideologia rządząca normami systemu nie pozwala na jawne i bezpośrednie uwzględnienie poziomów innych niż skanonizowane. To samo odnosi się do struktury społecznej i wszystkiego, co wiąże się z tym złożonym zjawiskiem.

Ideologia kultury oficjalnej jako jedynej możliwej do zaakceptowania w danym społeczeństwie spowodowała powstanie zmasowanego przymusu kulturowego. Za sprawą scentralizowanego systemu edukacji wpływa on na całe narody i uniemożliwia nawet kulturoznawcom obserwację i prawidłową ocenę roli dynamicznych napięć działających w obrębie kultury, gwarantujących jej utrzymanie. Podobnie jak w przypadku systemu przyrody, w którym niezbędna jest np. termoregulacja, systemom kulturowym również potrzebna jest równowaga chroniąca je przed załamaniem lub zniknięciem. Pełni ona funkcję regulacyjną, a uwidacznia się w opozycjach między poszczególnymi warstwami. W każdym systemie istnieje duże prawdopodobieństwo, że repertuary skanonizowane po pewnym czasie ulegną stagnacji, jeśli nie będą musiały konkurować $\mathrm{z}$ elementami nieskanonizowanymi, które często zagrażają ich pozycji. W obliczu wyzwań i presji ze strony tych ostatnich repertuary skanonizowane nie mogą pozostać bez zmian. Gwarantuje to ewolucję systemu, która jest jedynym środkiem jego zachowania. $Z$ drugiej strony w sytuacji, gdy presja nie znajduje ujścia, bywamy świadkami albo stopniowego porzucenia systemu i przejścia do innego (np. łacina wyparta przez dialekty romańskie), albo kompletnego upadku systemu w wyniku rewolucji (obalenie reżimu, całkowite zniknięcie kultywowanych dotychczas tradycji itd.).

Wydaje się, że w sytuacji, kiedy nie istnieje żadna „subkultura” (literatura bądź sztuka popularna, "kultura niska" w jakimkolwiek znaczeniu itd.) lub też gdy wywieranie faktycznej presji na kulturę skanonizowaną nie jest dopuszczalne, ta ostatnia ma niewielką szansę na zachowanie witalności. Przy braku stymulacji ze strony silnej „subkultury" każda działalność w obrębie kultury skanonizowanej skłania się ku stopniowej petryfikacji. Pierwszy krok w tym kierunku objawia się w znacznym ograniczaniu oraz $\mathrm{w}$ rosnącej stereotypizacji rozmaitych repertuarów. Dla systemu petryfikacja stanowi zakłócenie o charakterze operacyjnym: na dłuższą metę nie pozwala mu na sprostanie zmieniającym się potrzebom spoleczeństwa, w którym funkcjonuje. Ta niewydolność systemu, rozpatrywana w kategoriach nieadekwatności kulturowej (czego jak dotąd nikt prawie nie podjąl), może się manifestować na różne sposoby. W przypadku literatury - jednego z głównych systemów organizujących ludzką kulturę - nie musi wcale oznaczać natychmiastowej i nieuchronnej dezintegracji. Literatura jako instytucja socjokulturowa 
może w dalszym ciągu istnieć, natomiast miernikiem stopnia jej „adekwatności" jest pozycja, jaką zajmuje ona w obrębie kultury. Przykładowo sytuacja, w której literatura zostaje zepchnięta na peryferie kultury, może być widomym znakiem takiej nieadekwatności.

$\mathrm{Z}$ reguły centrum polisystemu pokrywa się $\mathrm{z}$ repertuarem skanonizowanym o największym prestiżu. Ostatecznie więc to grupa rządząca polisystemem decyduje o kanoniczności danego repertuaru, po czym albo przestrzega skanonizowanych przez siebie zasad (co $\mathrm{w}$ rezultacie pozwala jej kontrolować polisystem), albo w razie konieczności wprowadza w nich zmiany, aby utrzymać kontrolę. Z drugiej strony, jeśli postępowanie zgodnie $\mathrm{z}$ obiema wymienionymi procedurami nie przyniesie efektu, zarówno sama grupa, jak i skanonizowany przez nią repertuar zostaną odsunięte na bok przez jakąś inną grupę, która dąży do opanowania centrum, kanonizując odmienny repertuar. Tym, którzy nadal starają się przestrzegać zasad raz wypartego repertuaru, rzadko kiedy udaje się przejąć kontrolę nad centrum polisystemu; z reguły można ich odnaleźć na peryferiach repertuaru skanonizowanego, określanych (przez przedstawicieli kultury oficjalnej) pejoratywnym mianem epigonów. Ponieważ jednak polisystemy mogą ulegać stagnacji, bywa, że to właśnie epigoni przez długi czas zachowują pewien ustalony repertuar, utożsamiając się w końcu - ze stratyfikacyjnego punktu widzenia - z grupą, która pierwotnie zainicjowała ten stan rzeczy.

\subsubsection{System - repertuar - teksty}

W obrębie (poli)systemu to repertuar jest obszarem, w którym kanoniczność objawia się w najbardziej konkretny sposób. Repertuar może być albo skanonizowany, albo nieskanonizowany, zaś system, do którego należy, może się sytuować w centrum lub na peryferiach. Oczywiście, kiedy system o pozycji centralnej zawiera repertuary skanonizowane, można $\mathrm{w}$ skrócie mówić o systemach skanonizowanych $\mathrm{w}$ przeciwieństwie do systemów nieskanonizowanych - mimo pewnej nieprecyzyjności, jaką wprowadza to do naszego języka. W niniejszym ujęciu repertuar rozumiany jest jako zespół praw i elementów (pojedynczych, powiązanych ze sobą bądź też występujących jako całościowe modele), które rządzą produkcją tekstów. Podczas gdy niektóre $\mathrm{z}$ tych praw i elementów zdają się mieć uniwersalne zastosowanie od momentu powstania pierwszych literatur, wiele $\mathrm{z}$ nich bez wątpienia podporządkowanych jest zmieniającym się warunkom w różnych epokach i kulturach. Ten właśnie lokalny i temporalny obszar repertuaru jest miejscem zmagań w systemie literackim (czy też $w$ każdym innym systemie semiotycznym). Jednakże 
w samym repertuarze nie ma nic, co by decydowało, która jego część może być (lub stać się) skanonizowana, a która nie - podobnie, jak rozróżnienie między językiem "standardowym", „wysokim", „wulgarnym” czy też slangiem nie jest zdeterminowane przez repertuar językowy, lecz przez system języka, tzn. zespół czynników funkcjonujący w społeczeństwie zaangażowanym w produkcję i odbiór wypowiedzi językowych. Te właśnie relacje systemowe precyzują zatem status określonych jednostek (cech, właściwości) w danym ,języku”. Dlatego też wybór pewnego zespołu cech przeznaczonych do użytku grupy o danym statusie jest dla samego zespołu kwestią uboczną. Podobnie status każdego repertuaru literackiego określają relacje panujące w (poli)systemie. Oczywiście, repertuar skanonizowany cieszy się poparciem elit (konserwatywnych lub nowatorskich), dlatego podlega ograniczeniom narzuconym przez wzorce kulturowe kierujące ich postępowaniem. Jeśli wyrafinowanie i ekscentryczność (czy też cechy przeciwne: prostolinijność i konformizm) są tym, czego domaga się elita, by zadowolić swój gust i sprawować kontrolę nad centrum systemu kulturowego, wówczas repertuar skanonizowany dopasowuje się do pożądanych cech tak ściśle, jak tylko możliwe.

Przy takim podejściu „literatura” nie może być rozumiana ani jako zbiór czy też - w bardziej zaawansowanym ujęciu - zespół tekstów, ani jako repertuar. Teksty i repertuary są tylko częściowymi przejawami literatury - przejawami, których zachowania nie sposób wytłumaczyć ich własną strukturą. Można je natomiast wyjaśnić na poziomie (poli)systemu literackiego.

Bez wątpienia teksty są najbardziej ewidentnym wytworem systemu literackiego, przynajmniej w wielu okresach jego historii ${ }^{7}$. Oczywiście, dla pojedynczego odbiorcy liczy się ostateczny efekt danej działalności: zazwyczaj głównym obiektem zainteresowania konsumenta są przedmioty dostarczane przez przemysł, nie zaś czynniki rządzące ich produkcją $\mathrm{w}$ fabryce. Trudno się jednak nie zgodzić, że dla kogoś, kto chce zrozumieć przemysł jako złożony ciąg rozmaitych czynności, sama analiza produktów nie wyczerpuje tej kwestii, nawet jeśli przyjąć, że to właśnie

7 Trudno tu wyeliminować wyobrażenia uświęcone tradycją, dlatego wydaje się „naturalne", że prođukcja i recepcja tekstów zawsze była najważniejszą formą działalności w „literaturze”. Tym niemniej w pewnych epokach tekst był raczej opcją marginalną, równoleglą wobec innych rodzajów działalności w systemie literackim - takich, jak pisarz czy też „wydarzenie totalne", kształt różnych wykonań. Pragnę tu nadmienić, iż bardzo często obrona tradycyjnych tekstow (i modeli) bynajmniej nie oznacza nadmiernego nimi zainteresowania, a raczej obojętność wobec nich. Utrwalane odpowiednio długo, "teksty" stopniowo stają się $w$ literaturze czynnikami marginalnymi. (Oczywiście, pojedyncze elementy tekstów, jak np. wersy, strofy, wybrane wyrażenia spotyka się jako cytaty, traktowane nawet $z$ dużą atencją, jednakże $w$ większości przypadków funkcjonują one $w$ kształcie wyrwanym $\mathrm{z}$ oryginalnego (kon)tekstu.) 
one stanowią jedyną rację bytu dla funkcjonowania przemysłu. W systemie literackim teksty nie tyle pełnią rolę $w$ procesach kanonizacji, ile raczej same są ich efektem. Jedynie dzięki swej funkcji reprezentowania pewnych modeli teksty stanowią aktywny czynnik w relacjach systemowych.

\subsubsection{Kanoniczność statyczna - kanoniczność dynamiczna}

$\mathrm{Z}$ tego względu konieczne jest precyzyjne rozróżnienie między dwoma odmiennymi zastosowaniami terminu „kanonicznośc”, z których jeden odnosi się do poziomu tekstów, drugi zaś do poziomu modeli. Czym innym bowiem jest wcielenie tekstu do kanonu literackiego, a czym innym - wprowadzenie go do pewnego repertuaru za pośrednictwem modelu, jaki reprezentuje. W pierwszym przypadku, który można nazwać kanonicznością statyczną, określony tekst zyskuje akceptację jako skończony produkt i zostaje wlączony do zespolu usankcjonowanych tekstów, które literatura (kultura) pragnie zachować. W drugiej sytuacji, którą określimy mianem kanoniczności dynamicznej, pewien model literacki zostaje ugruntowany jako zasada, która okazuje się produktywna w systemie poprzez jego repertuar. Ten drugi rodzaj kanonizacji w największym stopniu decyduje o dynamice systemu. Poza tym to właśnie on w zasadzie generuje kanon, który w takim ujęciu można postrzegać jako grupę tekstów ocalałych $\mathrm{z}$ walki o kanonizację; są one prawdopodobnie najbardziej wyróżniającymi się produktami pewnych modeli, którym udało się zdobyć silną pozycję. Oczywiście, każdy tekst kanoniczny może być w każdej chwili powtórnie wcielony do repertuaru, by znów stać się skanonizowanym modelem. Wówczas jego rola nie polega już na tym, że jest on wydajny jako skończony produkt, lecz na tym, że staje się potencjalnym kompletem instrukcji, tzn. modelem. Fakt, że dany tekst zostal kiedyś skanonizowany i stał się kanoniczny, tzn. usankcjonowany, może (choć nie musi) być jego zaletą w stosunku do produktów nie należących do kanonu, które w danej chwili nie mają żadnej pozycji.

Dyskutowano już o tym, że system, w którym istnieje pewien kanon, funkcjonuje lepiej niż taki, który go nie posiada. Kanon statyczny wydaje się być podstawowym warunkiem, aby dany system uznać za odrębną działalność w kulturze ${ }^{8}$. Jest również oczywiste, że na poziomie po-

8 Taka jest aktualna hipoteza w wielu badaniach kulturoznawczych. $\mathrm{Na}$ ten temat p. D. Segal, Israeli Contributions to Literary Theory, w: E. Ibsch (red.): Schwerpunkte der Literaturwissenschaft, Amsterdam 1982, s. 261-292 oraz R. Sheffy, Establishment and Canonization in the Evolution of Cultural Systems: The Popular Song as a Test Case, praca mgr w języku hebrajskim, streszczenie angielskie, Tel Aviv 1985; tejże, The Concept 
wierzchniowym producenci tekstów (pisarze) walczą o to, by ich utwory zostały dostrzeżone i zaakceptowane jako takie. Ale nawet dla nich samych tak naprawdę znaczenie ma to, by ich teksty były odebrane jako manifestacja, udana aktualizacja pewnego modelu godnego kontynuowania. Dla autora byłoby ogromnym rozczarowaniem, gdyby jego poszczególny tekst został zaaprobowany, ale model literacki zanegowany. $\mathrm{Z}$ punktu widzenia pisarza oznaczałoby to koniec jego produktywności, sygnał, że jego siła oddziaływania i sprawność twórcza uległy wyczerpaniu. Żaden twórca nie może spokojnie przejść do porządku dziennego nad sytuacją, kiedy zostaje uznany za wielkiego pisarza, ale odrzucony jako wzorzec do naśladowania przez żywą literaturę. Autorzy mający pełną świadomość swojej pozycji oraz charakteryzujący się elastycznością i zdolnością manewru zawsze próbowali wydostać się z takiego położenia, o ile się w nim znaleźli. Borys Eichenbaum pokazał, jak Lew Tołstoj zareagował na kontestację jego literackich modeli (podczas gdy uznanie dla samych tekstów było już zapewnione, podobnie jak osobista pozycja autora $\mathrm{w}$ historycznym kanonie), wprowadzając parokrotnie w ciągu swego życia całkowicie odmienne modele literackie. Podobny przypadek to kariera Augusta Strindberga, któremu kilka razy udało się utrzymać w centrum skanonizowanego repertuaru twórczego dzięki przerzucaniu się $\mathrm{z}$ jednego zespołu modeli na drugi. Inni pisarze (zapewne znaczna ich większość) na ogół pozostają wierni jednej grupie wzorców przez całe życie. Mogą co prawda tworzyć dzieła doskonalsze niż kiedyś zgodnie z tym samym (wcześniejszym) modelem, tracąc jednakże pozycję osiągniętą we współczesnej literaturze. Nie musi to jednak oznaczać utraty publiczności, która wraz z ulubionym autorem przemieszcza się z centrum na peryferie systemu literackiego. Jest to oczywisty dowód na to, że pisarze nie zdobywają swej rangi w systemie literackim poprzez teksty jako takie. Ci, którzy dopiero od niedawna zajmują centrum, nie muszą odmawiać dotychczasowym twórcom ich miejsca w kanonie statycznym, ale jednocześnie mogą ich nie akceptować jako modeli, według których mają powstawać nowe teksty. Niekiedy jednak taka dyskwalifikacja wiąże się - przynajmniej $\mathrm{w}$ początkowym stadium - $\mathrm{z}$ wykluczeniem $\mathrm{z}$ kanonu również i zdetronizowanych pisarzy, tzn. ich tekstów.

\subsubsection{Typy pierwotne - typy wtórne}

Jak stwierdzono powyżej (p. 2.2.), transfer niekoniecznie musi być skojarzony ze specyficznymi procedurami narzuconymi właściwościom, które się z nimi wiążą. Innymi słowy, transfer jest skorelowany z trans-

of Canonicity in Polysystem Theory, „Poetics Today” 11:3 (1990), s. 511-522. W pracach tych przedmiot dyskusji potraktowano w sposób niezwykle oryginalny i inspirujący. 
formacją. Procedury te, występujące w różnych postaciach, można niekiedy zdefiniować jako wstępne warunki transferu, podczas gdy w innych sytuacjach bywają one jego rezultatem. To, czy wspomniane procedury są jednym, czy drugim, zależy od specyficznego stanu polisystemu, jak również od naszej umiejętności wyodrębniania pewnych ogólnych zasad korelacji między transferem a transformacją. Przede wszystkim fakt, że w danym przypadku mają zastosowanie dwie odrębne zasady, nie jest całkiem jasny, skoro procedury te są ściśle związane $\mathrm{z}$ omawianym procesem, zaś w pewnych okresach w historii literatury czy tėz języka wykazują tendencję do działania niemal zawsze w obrębie określonych warstw. Dlatego może się wydawać, że procedury te są w pewnym sensie wymienne. Niestety, w ten sposób kwestię tę ukazywaly wcześniejsze prace piszącego te słowa, co zostało skorygowane $\mathrm{w}$ artykule The Polysystem Hypothesis Revisited ${ }^{9}$. Jako zasade rządzącą procedurami związanymi z transferem (oraz ze stratyfikacją polisystemu w ogóle) zaproponowałem podział na typy „pierwotne” i „wtórne"10. Ponieważ jednak w analizowanym wówczas korpusie tekstów literackich typy „pierwotne" na ogół pojawiały się wyłącznie w repertuarze skanonizowanym, zaś typy „wtórne” - w nieskanonizowanym, zacząłem stosować termin "system pierwotny" w znaczeniu "skanonizowanego repertuaru posiadającego typy pierwotne". Postępowanie to jest nieadekwatne, ponieważ zaciemnia przedmiot badań, a ponadto okazuje się błędne, jeśli wziąć pod uwagę okresy inne niż te, które wówczas analizowałem ${ }^{11}$.

Opozycja „pierwotny - wtórny” jest opozycją między „nowatorstwem” a "konserwatyzmem" w repertuarze. Jeśli ma on ugruntowaną pozycję, a wszystkie modele pochodne będące jego elementami są skonstruowane w sposób całkowicie zgodny $\mathrm{z}$ dopuszczonymi przezeń zasadami, mamy do czynienia $z$ repertuarem (i systemem) konserwatywnym. Każdy należący do niego indywidualny produkt (wypowiedź, tekst) jest $\mathrm{w}$ dużym stopniu przewidywalny, zaś każde odstępstwo będzie poczytane za ekstrawagancję. Produkty takie określam mianem „wtórnych”. Z kolei poszerzenie i zrestrukturyzowanie repertuaru poprzez wprowadzenie nowych elementów, skutkiem czego każdy produkt staje się mniej przewidywalny, jest cechą repertuaru (i systemu) nowatorskiego. Oferowane przezeń

9 I. Even-Zohar, The Polysystem Hypothesis Revisited, w: tenże, Papers in Historical Poetics, Tel Aviv 1978, s. 28-35.

10 Tenże, Papers in Historical Poetics, Tel Aviv 1978, s. 14-20.

11 Por. S. Yahalom, Relations entre les littératures anglaise et française au $18 e$ siécle, Tel Aviv 1978 (praca magisterska w języku hebrajskim, streszczenie francuskie); Du non littéraire au littéraire, „Poétique“ 44 (1980), s. 406-421. R. Drory, The Emergence of Jewish-Arabic Literary Contacts at the Beginning of the Tenth Century, Tel Aviv 1988 [= Literature, Meaning, Culture 17; praca w języku hebrajskim]. 
modele stanowią typy „pierwotne”: wstępnym warunkiem ich funkcjonowania jest przerwanie ciągłości ustalonych modeli (bądź też ich elementów). Oczywiście jest to wyobrażenie czysto historyczne. Model „pierwotny", dopuszczony do centrum systemu skanonizowanego, nie potrzebuje wiele czasu, by stać się modelem "wtórnym", jeśli tylko będzie utrwalany odpowiednio długo.

Dla ewolucji systemu konkurencja między opcjami pierwotnymi i wtórnymi ma tak samo decydujące znaczenie, jak napięcie (i rywalizacja) między niższymi i wyższymi jego warstwami. Rzecz jasna, zmiana pojawia się tylko wtedy, gdy model pierwotny zaczyna dominować $w$ repertuarze, a następnie w (poli)systemie; jego ugruntowanie jest oznaką stabilizacji i ponownego konserwatyzmu. Zazwyczaj proces utrwalania nowych modeli rządzi się własnymi, specyficznymi prawami. Przykładowo, do tej pory nie zaobserwowano, by jakikolwiek model pierwotny zdołał się utrzymać bez towarzyszących mu modyfikacji strukturalnych, które można by określić ad hoc mianem "uproszczenia”. Nie oznacza to bynajmniej, że modele pierwotne są bardziej złożone i wyrafinowane od wtórnych, tylko że w miarę ich utrwalania w obrębie wyłaniających się $\mathrm{z}$ nich ostatecznie modeli wtórnych ma miejsce proces redukcji. I tak np. modele heterogeniczne ulegają przekształceniu w modele homogeniczne; ilość niezgodnych ze sobą wzorców (np. różnych rodzajów „wieloznaczności”) w ramach tej samej struktury ulega zmniejszeniu; relacje złożone zostają stopniowo zastąpione mniej złożonymi itd. Oczywiście mają też miejsce procedury odwrotne, kiedy model wtórny ulega manipulacji w taki sposób, że zostaje praktycznie przekształcony w model pierwotny.

Jak wspomniano powyżej, kanoniczność niekoniecznie musi oznaczać pierwotność, choć takie utożsamienie może być trafne w odniesieniu do czasów nowszych, tzn. począwszy od epoki romantyzmu. Dlatego ważne jest odkrycie rodzaju relacji panujących między kanonicznością a nowatorstwem. Im bliżej obserwujemy literaturę pod tym kątem, tym bardziej oczywisty staje się fakt, że mamy do czynienia z powszechnym mechanizmem nie tyle ściśle literackim, ile semiotycznym. Ponieważ systemy rządzone są przez tych, którzy je kontrolują, narzędzia będące przedmiotem rywalizacji zależą od ich względnej skuteczności w sprawowaniu władzy nad systemem. Tak więc jeśli kontrolę można zdobyć jedynie za sprawą „zmiany”, to właśnie ona staje się wiodącą, powszechną zasadą. Inaczej natomiast będzie dopóty, dopóki to raczej utrwalanie wzorów, nie zaś wprowadzanie innowacji będzie spełniać oczekiwania tych, którzy mogą więcej stracić na zmianach. Oczywiście, kiedy już kontrola zostanie przejęta, nowy repertuar nie będzie dopuszczać tych elementów, które mogłyby zagrozić jego dominacji w systemie. Proces „uwtórniania” tego, co pierwotne, okazuje się zatem nieunikniony. Potę- 
guje go nadto równoległy mechanizm sekundaryzacji, zgodnie z którym system jest $\mathrm{w}$ stanie stłumić tendencje nowatorskie. W procesie tym nowe elementy są niejako ponownie przekształcane w stare kategorie; nowym przedstawicielom narzuca się $w$ ten sposób poprzednie funkcje, nie zmieniając tych ostatnich. Podobnie jak w przypadku, gdy nowy ustrój kontynuuje pracę instytucji byłego systemu, przekazując ich zadania nowym gremiom, tak samo pierwotny model literacki, stopniowo zmieniany, z upływem czasu zasila zasób modeli wtórnych z poprzedniego stadium. Mówiąc językiem semiotyki, jest to mechanizm, zgodnie z którym to, co początkowo mniej zrozumiałe i trudniejsze do rozszyfrowania, staje się prostsze do zdekodowania i zrozumienia. To, co mniej znane i przez to budzące obawy, stawiające nowe wyzwania, obarczone znacznym ładunkiem informacji, staje się bardziej znajome, mniej onieśmielające itd. Jak pokazuje doświadczenie, przeważająca większość odbiorców kultury $\mathrm{w}$ istocie woli właśnie taką sytuację i jeśli ktoś chce mieć nad nimi kontrolę, efekt działania tego mechanizmu będzie w pełni odpowiadać ich preferencjom.

\subsection{Relacje wewnętrzne i zewnętrzne}

Zasady i właściwości przedstawione powyżej dla relacji panujących wewnątrz polisystemu zdają się potwierdzać również $\mathrm{w}$ odniesieniu do jego relacji zewnętrznych. W tych ostatnich uczestniczą dwa sąsiadujące ze sobą systemy: więkssza całość należąca do danej społeczności oraz całość lub jej część należąca do innych społeczności, tego samego lub innego rzędu (rodzaju).

\subsubsection{Relacje wewnętrzne}

W pierwszym z wymienionych przypadków taki punkt widzenia opiera się na założeniu, że każdy (poli)system semiotyczny - taki, jak literatura czy język - jest tylko częścią składową większego (poli)systemu kultury, któremu jest podporządkowany i wobec którego jest izomorficzny, w związku z czym łączy się $\mathrm{z}$ większą całością oraz z innymi jej komponentami. W kwestii tak złożonej, jak korelacja literatury z językiem, społeczeństwem, gospodarką, polityką, ideologią itd., teoria polisystemów pozwala wysunąć hipotezy mniej naiwne i redukcjonistyczne niż inne propozycje. I tak np. nie wymaga już założenia, że fakty społeczne muszą znaleźć natychmiastowy, jednokierunkowy i jednoznaczny wyraz na poziomie repertuaru literackiego, jak tego chciała prymitywna 
socjologia czy też historia idei, nie wyłączając (ortodoksyjnego) marksizmu. Skomplikowane powiązania między tymi systemami kulturowymi - postrzeganymi jako układy o naturze izomorficznej, funkcjonujące jedynie w obrębie pewnej kulturowej całości - można obserwować na podstawie obustronnej wymiany międzysystemowej, która często ma miejsce nie wprost, lecz poprzez pewne narzędzia przekazu, niejednokrotnie zaś za pośrednictwem peryferii. Zjawisko to ukazano na przykładzie różnych warstw funkcjonujących głównie na peryferiach (np. przekład literacki). Obszerny materiał i szczegółową analizę na ten temat można znaleźć w pracach następujących autorów: Toury ${ }^{12}$, Shavit i Shavit ${ }^{13}$, Shavit ${ }^{14}$, Yahalom ${ }^{15}$, Sheffy ${ }^{16}$ i inni.

Ponadto jeśli przyjmiemy, że system literatury jest izomorficzny np. z systemem społecznym, hierarchie obydwu możemy sobie wyobrazić wyłącznie jako krzyżujące się ze sobą. Myśl, iż literatura o mniejszym stopniu stratyfikacji może się stać bardziej uwarstwiona (co zaproponowałem jako powszechną zasadę systemową ${ }^{17}$ ), da się zatem zrozumieć na podstawie homologicznych związków między literaturą a społeczeństwem. To samo odnosi się do innych hipotetycznych relacji, których istnienie w polisystemie literackim zakłada teoria polisystemów. Tak więc koncepcja literatury jako odrębnej, na poły niezależnej instytucji socjokulturowej jest zasadna tylko wtedy, gdy jej polisystem - jak każdy inny system socjokulturowy - wyobrazimy sobie jako jednocześnie autonomiczny i heteronomiczny wobec wszystkich innych współistniejących systemów. Nie da się zaprzeczyć, że fakty zinstytucjonalizowanego „życia literackiego"18 (na które składają się np. ideologie literackie, oficyny wydawni-

12 G. Toury, Translational Norms and Literary Translation into Hebrew, 1930-1945, Tel Aviv 1977 (praca w języku hebrajskim); tenże, In Search of a Theory of Translation, Tel Aviv 1980.

13 Z. Shavit i Y. Shavit, Hebrew Crime Stories during the 1930s in Palestina, w: „Ha-Sifrut” 18/19, 1974, s. 30-73 (streszczenie angielskie: s. iv).

14 Z. Shavit, Translation of Children's Literature as a Function of Its Position in the Literary Polysystem, w: Modern Realistic Stories for Children and Young People, R. Majonica (red.), Monachium 1978, s. 180-187 (powtórzone w: „Poetics Today” 2(4), s. 171-179); Z. Shavit, The Ambivalent Status od Texts: The Case of Children's Literature, „Poetics Today" 1(3), 1980, s. 75-86; tenże, Poetics of Children's Literature, Ateny-Londyn 1986, (red.), The History of the Cultural Center in Palestine, t. 1: Institutions, t. 2: Texts. Jerozolima (praca w języku hebrajskim).

${ }^{15} \mathrm{~S}$. Yahalom, Relations entre les littératures anglaise et française au 18 e siécle, op. cit.; Du non littéraire au littéraire, op. cit.

${ }^{16}$ R. Sheffy, Establishment and Canonization..., op. cit.

17 Por. I. Even-Zoh ar, Papers in Historical Poetics, op. cit., s. 39.

18 Eichenbaum używa terminu litieraturnyj byt (zob. Eichen bau m, Moj wremennik, Leningrad 1929, zwł. s. 49-86 i 109-114), który jest thumaczony w języku polskim jako życie literackie (zob. Eich en bau m, Szkice o prozie i poezji, op. cit., s. 387-402). 
cze, krytyka, grupy pisarzy czy też inne ośrodki dyktujące reguły smaku i obowiązujące normy), choć zachowują się jak odrębny, na wpół niezależny system socjokulturowy rządzący się własnymi prawami, muszą być również uznane za niezbędne czynniki systemu literackiego w ścisłym tego słowa znaczeniu. Refleksja ta, raczej mglista nawet w schyłkowej fazie rosyjskiego formalizmu, zdaje się być kwestią najważniejszą w późnych pracach Eichenbauma; badacz ten przekroczył w ten sposób nienaruszalne granice, do których inni nawet nie próbowali się zbliżyć. I w tym jednak przypadku sprawy te zostały raczej zasugerowane niż sformułowane explicite.

\subsubsection{Relacje zewnętrzne}

Te same hipotezy znajdują zastosowanie i w drugim przypadku, tzn. w kwestii relacji, jakie system utrzymuje z układami kontrolowanymi przez inne społeczności. Tak samo, jak zespół zjawisk oddziaływających na daną społeczność można postrzegać jako system tworzący część większego polisystemu, który z kolei jest tylko komponentem jeszcze większego polisystemu „całości kultury” wspomnianej społeczności, tak samo ten ostatni można uznać za część „mega-polisystemu”, porządkującego i kontrolującego kilka społeczności. Jak pokazuje historia, ,jednostki" tego typu nie mają bynajmniej wyraźnie zarysowanych konturów ani też nie są ustanowione raz na zawsze. Jest raczej odwrotnie, skoro granice oddzielające przyległe systemy cały czas się zmieniają i to nie tylko w obrębie systemów, ale też między nimi. Samo wyobrażenie, że coś znajduje się „w obrębie”, a coś „pomiędzy”, nie może być rozumiane statycznie ani tym bardziej przyjęte za pewnik.

Spójrzmy na tak ewidentny przypadek, jak społeczności europejskie oraz literatura i kultura każdej z nich. Oczywiście, w średniowieczu Europa Srodkowa i Zachodnia stanowiła jeden polisystem. Jego centrum zajmowała literatura pisana po łacinie, podczas gdy tworzone równocześnie teksty w dialektach (pisane czy też mówione) należały do peryferii. W wyniku długotrwałego procesu redukcji system ten - wraz z utrwalonym, skanonizowanym repertuarem - w końcu się załamał i około połowy XVIII w. zostal zastąpiony przez szereg mniej lub bardziej niezależnych, jednojęzykowych (poli)systemów, których współzależność od siebie stopniowo coraz bardziej traciła na znaczeniu - przynajmniej z punktu widzenia odbiorców i dominujących ideologii. Mimo to nie ulega wątpliwości, że - aby nie tylko móc opisać ogólne zasady interferencji, ale też z niejaką dokładnością wyjaśnić ich charakter i przyczyny - trzeba założyć hipotezę stratyfikacji. W miarę wyodrębniania się poszczególnych 
narodów europejskich, rozwijających każdy własną kulturę - której najbardziej wyraźnym i oczywistym narzędziem była nowo tworzona literatura, język i oficjalna historia - od samego początku nieuchronnie dochodziły do głosu pewne relacje na płaszczyźnie: centrum - peryferie. Kultury powstałe wcześniej i należące do narodów, które - za sprawą bezpośredniej dominacji czy też prestiżu - miały wpływ na inne nacje, stawały się źródłem dla młodszych kultur (nie wyłączając tych reaktywowanych w czasach nam bardziej współczesnych). W rezultacie pojawiła się nieunikniona rozbieżność między przekazywanymi modelami, częstokroć reprezentującymi typy wtórne ( $\mathrm{z}$ tak oczywistej przyczyny, jak łatwość identyfikacji i wyodrębnienia zasad konstrukcyjnych) a modelami oryginalnymi, jako że te ostatnie zostały do tego czasu z dużym prawdopodobieństwem wyparte $\mathrm{z}$ centrum systemu na peryferie.

Ciekawym przypadkiem badawczym, w którym tego typu relacje wydają się dość ewidentne i możliwe do poddania szczegółowej analizie, są przekłady tekstów z młodszej literatury na język innego systemu literackiego, z którego ta pierwsza pierwotnie czerpała wzorce, tworząc zaczątek własnego repertuaru ${ }^{19}$. Nic dziwnego, iż przekłady są wówczas kształtowane zgodnie $\mathrm{z}$ najbardziej wtórnymi modelami, jakimi dysponuje literatura docelowa. Publiczność literacka sytuująca się w jej centrum może odbierać takie tłumaczenia jako produkty „epigońskie”, o ile literatura docelowa znajduje się w stanie dynamicznego rozwoju. Jednocześnie zaś może się okazać, że tylko taka forma przekładu usatysfakcjonuje inne grupy odbiorców docelowych, skoro jedynie w ten sposób potrafią oni zidentyfikować tekst jako odpowiednio „literacki”, a więc możliwy do zaakceptowania. Naturalnie taka cecha charakterystyczna wspomnianych utworów nie ma żadnego znaczenia funkcjonalnego dla ich roli (czy też dla roli wzorców leżących u ich podstaw) w literaturze, do której należą. Rozważenie takich okoliczności jest nieodzowne tylko wtedy, gdy interesuje nas wykrycie procesów i procedur powodujących ewolucję czy też przetrwanie systemu.

Reasumując, głównym celem i możliwością zastosowania teorii polisystemów jest badanie szczególnych warunków, w jakich zachodzą interferencje między literaturami, w wyniku czego pewne właściwości przekazywane są z jednego polisystemu do drugiego. Przykładowo, jeśli przyjmiemy hipotezę, że cechy typowe dla peryferii prawdopodobnie przenikną do centrum, gdy tylko zdolność tego ostatniego (tzn. repertu-

19 Przykłady tego typu można znaleźć $w$ wielu francuskich czy niemieckich przekładach $\mathrm{z}$ różnych literatur, które zbudowały swoje repertuary na podwalinach piśmiennictwa francusko- czy niemieckojęzycznego - np. XIX-wieczna poezja flamandzka tłumaczona na francuski. Inny przypadek to rosyjskojęzyczne przekłady tekstów hebrajskich $z$ końca XIX i początku XX w., które z kolei wzorowano na repertuarze literatury rosyjskiej. 
aru centralnego) do spełniania określonych funkcji ulegnie osłabieniu (drugie prawo Szkłowskiego), to nie ma sensu zaprzeczać, że dokładnie ta sama zasada działa na płaszczyźnie międzysystemowej. Podobnie też polisystemowa struktura poszczególnych literatur pozwala wyjaśnić skomplikowane procesy interferencji, które - wbrew powszechnemu mniemaniu - odbywają się często za pośrednictwem peryferii. Ignorując te zjawiska, rezygnujemy z możliwości wyjaśnienia, dlaczego w repertuarze pojawiają się i zaczynają funkcjonować nowe jednostki. Teksty paraliterackie, przekłady, literatura dla dzieci - wszystkie te warstwy zaniedbywane przez współczesne literaturoznawstwo stanowią przedmiot badań absolutnie konieczny do zrozumienia, dlaczego i w jaki sposób dochodzi do transferów zarówno w obrębie systemów, jak i między nimi20.

\subsection{Stabilność i niestabilność; pojemność systemu}

Aby system socjokulturowy mógł działać niezależnie od systemów zewnętrznych (czyli równoległych, należących do innych społeczności), musi być spełnionych kilka warunków. Istnieją wszelkie powody, by przypuszczać, że jednym $\mathrm{z}$ nich jest heterogeniczność, gdzie zasada proliferacji wydaje się mieć uniwersalne znaczenie. Propozycja ta, wysunięta przeze mnie w roku $1975^{21}$ (wówczas nieco inaczej sformułowana), oznacza, że system - aby sprostać wszystkim potrzebom - usilnie stara się uaktywnić rosnący inwentarz alternatywnych opcji. Skoro tylko dany system zgromadzi wystarczający ich zasób, istnieją duże szanse, że pozwoli mu się on utrzymać i przetrwać, o ile warunki nie ulegną gwałtownej zmianie. W przeciwnym wypadku transfer międzysystemowy pozostaje jedynym, a przynajmniej najważniejszym rozwiązaniem, dokonując się natychmiast pomimo oporu. Wiedza, jak duży powinien być ten „wystarczający zasób" zapewniający odpowiednie funkcjonowanie systemu, byłaby oczywiście niezmiernie pożądana i oznaczałaby duży krok naprzód w rozwoju naszych teorii. Jednak w chwili obecnej nie mamy do niej dostępu, nawet jeśli na poziomie opisowym można mówić o repertuarach „minimalnych”, bez których żaden system literacki nie zdołałby przetrwać. Badania nad stopniowym wykształcaniem się repertuarów (literackich) pokazały, że już od samego początku żadna literatura nie poprzestaje na niewielkim inwentarzu opcji. To samo odnosi się do syste-

${ }^{20}$ Dokładniejsza analiza na ten temat znajduje się $\mathrm{w}$ artykule tegoż autora w rozdziale Laws of Literary Interference w tej samej pracy, której wyjątek stanowi niniejszy tekst, s. 53-72 [przyp. thum.].

21 I. Even-Zohar, Papers in Historical Poetics, op. cit., s. 43. 
mu literackiego jako większej całości. Innymi słowy potwierdza się fakt, że wraz z powstaniem systemu zaczyna działać zasada proliferacji.

Powyższe uwagi mogą nasuwać myśl, że dla systemu korzystna jest permanentna niestabilność. Tak jednak nie jest. Na poziomie systemu niestabilność nie jest tożsama ze zmianą, podobnie jak stabilność nie oznacza tego samego, co petryfikacja. Inaczej mówiąc, stabilność repertuaru względnie jej brak niekoniecznie musi odzwierciedlać czy też generować stabilność bądź niestabilność systemu. System, który nie potrafi się utrzymać przez dany okres czasu i raz po raz znajduje się na krawędzi załamania, jest niestabilny $z$ funkcjonalnego punktu widzenia, podczas gdy system podlegający stałym i ciągłym, a jednocześnie kontrolowanym przemianom można uznać za stabilny po prostu dlatego, że udaje mu się przetrwać. Tylko takie właśnie, trwałe systemy mogą się ostać, podczas gdy inne zwyczajnie zanikają. Dlatego „kryzysy” czy „katastrofy” w polisystemie (tzn. zjawiska wskazujące na konieczność radykalnej zmiany za sprawą transferu wewnętrznego lub zewnętrznego), jeśli tylko są przez system kontrolowane, stanowią oznakę witalności, nie zaś degeneracji. Niebezpieczeństwem mogą się okazać jedynie te zmiany, które wymknęły się spod kontroli. Oczywiście, z punktu widzenia tych, którzy zajmują w systemie pozycję na jakimkolwiek poziomie, każda zmiana, której nie są oni w stanie opanować, stanowi groźbę dla ich pozycji niekoniecznie jednak dla systemu jako takiego. Historia zna przypadki, kiedy zagrożony repertuar naraża na niebezpieczeństwo cały system, jednak przeważnie sytuacja taka jest rezultatem uprzedniej długotrwałej stagnacji, przede wszystkim nie dopuszczającej „normalnej dynamiki”.

Z języka angielskiego przełożyła Katarzyna Lukas 